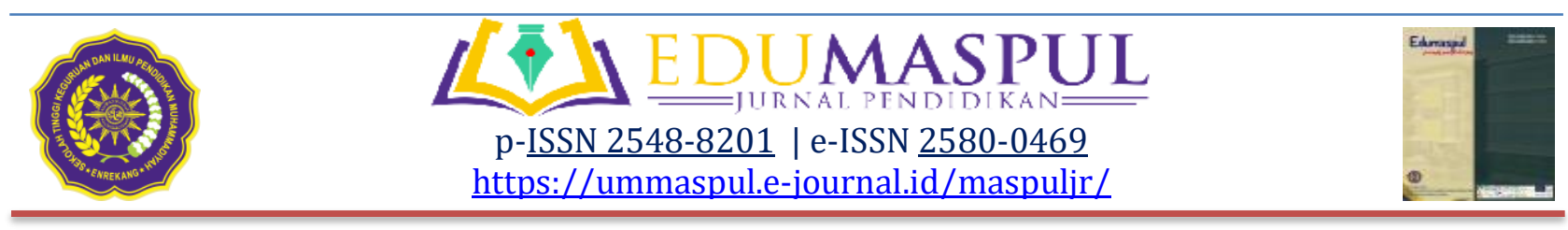

\title{
Pengembangan Perangkat Pembelajaran Matematika Menggunakan Metode Discovery Learning Berbasis GRANDER di Sekolah Dasar
}

\author{
Irmawati $\mathbf{M}^{1} \bowtie$ Rukli $^{2}$, Baharullah $^{3}$ \\ 1,2,3 Magister Pendidikan Dasar, Universitas Muhammadiyah Makassar, Indonesia \\ $\triangle$ Corresponding email: ${ }^{1}$ irmawatim65@yahoo.com
}

\begin{abstract}
Receive: 25-09-2019
Accepted: 04-10-2019

Published: 09-10-2019

Abstrak. Perangkat pembelajaran sangat penting digunakan dalam proses pembelajaran karena sangat menentukan tujuan yang akan dicapai. Adapun hasil observasi awal yang dilakukan disalah satu sekolah yang ada di Makassar menunjukkan bahwa hasil belajar murid belum mencapai ketuntasan klasikal, aktivitas murid sangat kurang dan murid tidak mengetahui konsep dari materi yang diajarkan sehingga dibutuhkan suatu perangkat pembelajaran yang bisa melibatkan murid dalam proses pembelajaran. Penelitian ini bertujuan untuk mengetahui validitas, praktikalitas dan efektivitas perangkat pembelajaran matematika menggunakan metode discovery learning berbasis GRANDER pada murid kelas VI SD. Penelitian ini adalah penelitian pengembangan menggunakan model 4-D. Subjek penelitian adalah adalah murid kelas VI A SD Inpres Minasa Upa yang terdiri dari 22 murid sebagai sekolah simulasi, murid kelas VI B SD Inpres Karunrung yang terdiri dari 24 murid dan murid kelas VI A SD Negeri Minasa Upa 1 Kota Makassar yang terdiri dari 24 murid sebagai sekolah uji coba perangkat. Data dikumpulkan menggunakan lembar validasi, angket respon murid, lembar pengamatan keterlaksanaan perangkat pembelajaran, instrumen penilaian hasil belajar, lembar pengamatan aktivitas murid dan lembar pengamatan kemampuan guru dalam mengelola pembelajaran. Teknik analisis data yang digunakan adalah analisis deskriptif. Hasil penelitian menunjukkan bahwa perangkat pembelajaran matematika berbasis GRANDER dinyatakan valid dan reliabel. Perangkat pembelajaran berbasis GRANDER dinyatakan praktis karena dua indikator tercapai yaitu respon murid dan keterlaksanaan perangkat pembelajaran. Perangkat pembelajaran berbasis GRANDER dinyatakan efektif karena tiga indikator tercapai yaitu hasil belajar, aktivitas murid dan kemampuan guru dalam mengelola pembelajaran.
\end{abstract}

Kata Kunci: Perangkat Pembelajaran Matematika, Discovery Learning, GRANDER

Abstract. Learning tools are very important to be used in the learning process because they determine the objectives to be achieved. The results of preliminary observations conducted at one of the schools in Makassar indicate that student learning outcomes have not yet reached classical completeness, student activities are very lacking and students do not know the concepts of the material being taught so we need a learning device that can involve students in the learning process. This study aims to determine the validity, practicality and effectiveness of mathematics learning tools using the GRANDER-based discovery learning method in grade VI elementary school students. This research is a development study using a 4-D model. The subjects of the study were students of class VI A of SD Inpres Minasa Upa consisting of 22 students as a simulation school, students of class VI B of SD Inpres Karunrung consisting of 24 students and students of class VI A of SD Negeri Minasa Upa 1 Makassar consisting of 24 students as a device trial school. Data were collected using validation sheets, student response questionnaires, observation sheets for the implementation of learning tools, learning 
outcome assessment instruments, observation sheets for student activities and observation sheets for teachers' ability to manage learning. The data analysis technique used is descriptive analysis. The results showed that the GRANDER-based mathematics learning device was declared valid and reliable. GRANDERbased learning tools are declared practical because two indicators are achieved namely student response and the implementation of learning tools. GRANDER-based learning tools are declared effective because three indicators are achieved namely learning outcomes, student activities and the ability of teachers to manage learning.

Keywords: Mathematics Learning Tools, Discovery Learning, GRANDER

\section{PENDAHULUAN}

Matematika sebagai salah satu ilmu pendidikan telah banyak berkembang dewasa ini. Matematika berfungsi mengembangkan kemampuan menghitung, mengukur, menemukan dan menggunakan rumus matematika yang dapat menunjang pemahaman konsep murid kaitannya dalam kehidupan sehari-hari.

Belajar matematika tidak cukup mengenal konsep, namun dapat mempergunakan konsep tersebut untuk menyelesaikan masalah, baik masalah yang berhubungan dengan matematika ataupun masalah yang dijumpai dalam kehidupan sehari-hari. Matematika bagi sebagian besar murid dianggap sebagai pelajaran yang sulit untuk dipahami, sebab matematika selalu dihubungkan dengan angka dan rumus.

Kemampuan matematika murid Indonesia ditinjau dari Programme for International Student Assessment (PISA) di bidang matematika pada tahun 2003, murid Indonesia berada pada peringkat ke-39 dari 40 negara sampel, selanjutnya hasil PISA tahun 2006 Indonesia peringkat ke-38 dari 41 negara, hasil PISA tahun 2009 yaitu peringkat ke-61 dari 65 negara, kemudian tahun 2015 Indonesia peringkat 62 dari 70 negara peserta dengan skor 403 dari rata-rata skor OECD 493. Menandakan bahwa kemampuan matematika murid Indonesia masih tergolong rendah sehingga kurikulum sangat menentukan kualitas pendidikan.

Penerapan Kurikulum Tingkat Satuan Pendidikan (KTSP) masih terdapat beberapa permasalahan, salah satunya adalah kurikulum ini tidak mengakomodasi pergeseran paradigma pembelajaran abad 21 .
Paradigma teaching telah bergeser menjadi paradigma learning (Hidayat, 2013). Paradigma belajar abad sebelumnya lebih ditekankan pada paradigma teaching yaitu guru sebagai pusat belajar. Paradigma belajar pada abad 21 adalah paradigma learning yaitu murid yang menjadi pusat dalam proses pembelajaran. Paradigma ini menekankan bahwa guru tidak lagi menjadi satu-satunya sumber belajar, dan peranannya telah bergeser sebagai fasilitator belajar. Sebagai fasilitator belajar, guru dituntut untuk lebih kreatif dan inovatif dalam melaksanakan pembelajaran (Abduh, 2015).

Berdasarkan hasil observasi awal dan wawancara di kelas VI di salah satu sekolah yang ada Kota Makassar ditemukan beberapa kendala sebagai berikut. Pertama, hasil belajar murid belum mencapai ketuntasan klasikal. Jumlah murid 22 sebanyak 7 murid tidak tuntas (32\%) dan 15 murid tuntas (68\%) dengan KKM 72. Kedua, pada saat proses pembelajaran guru tidak menggunakan alat peraga. Ketiga, pada saat proses wawancara dengan guru kelas VI mengenai silabus dan rencana pelaksaanaan pembelajaran (RPP) yang digunakan guru tersebut masih berpedoman pada perangkat pembelajaran tematik sedangkan perangkat pembelajaran khusus matematika di kelas tinggi saat ini sudah terpisah dari mata pelajaran lainnya. Keempat, masih ada murid yang tidak mengetahui konsep dari materi yang diajarkan. Kelima, pada saat proses pembelajaran guru lebih aktif dibandingan murid.

Aktivitas belajar adalah aktivitas yang bersifat fisik maupun mental. Dalam proses belajar kedua aktivitas itu harus saling berkaitan. Lebih lanjut lagi Piaget 
menerangkan jika seorang anak berfikir tanpa berbuat sesuatu, berarti anak itu tidak berfikir (Sardiman, 2011). Oleh karena itu agar murid aktif berpikir maka murid harus diberi kesempatan untuk mencari pengalaman sendiri serta dapat mengembangkan seluruh aspek pribadinya. Murid pun harus lebih aktif dan mendominasi sehingga dapat mengembangkan potensi yang ada dalam dirinya. Kendala tersebut hendaknya dapat diminimalisir dengan adanya pengembangan perangkat pembelajaran menggunakan metode maupun pendekatan pembelajaran yang melibatkan murid aktif berpikir.

Pengembangan perangkat pembelajaran adalah serangkaian proses atau kegiatan yang dilakukan untuk menghasilkan suatu perangkat pembelajaran berdasarkan teori pengembangan yang telah ada. Tujuannya adalah sebagai pengembangan untuk mendapatkan prototipe produk dan perumusan saran-saran metodologis untuk pendesainan dan evaluasi prototipe tersebut (Ibrahim, 2003). Menurut Zuhdan (2011) perangkat pembelajaran adalah alat atau perlengkapan untuk melaksanakan proses yang memungkinkan pendidik dan peserta didik melakukan kegiatan pembelajaran. Permendikbud No. 22 Tahun 2016 tentang standar proses pendidikan dasar dan menengah disebutkan bahwa penyusunan perangkat pembelajaran merupakan bagian dari perencanaan pembelajaran. Perencanaan pembelajaran meliputi penyusunan rencana pelaksanaan pembelajaran dan penyiapan media dan sumber belajar, perangkat penilaian pembelajaran, dan skenario pembelajaran. Penyusunan silabus dan RPP disesuaikan metode atau pendekatan pembelajaran yang digunakan.

Metode pembelajaran adalah cara atau seni untuk menggunakan semua sumber belajar dalam upaya mencapai tujuan pembelajaran (Wena, 2011). Menurut Nasution (2017) bahwa metode ceramah dalam pembelajaran dapat melatih murid untuk menggunakan pendengarannya dengan baik serta dapat menyimpulkan materi yang didengar. Menurut Aqib (2014) metode diskusi merupakan interaksi antara murid dengan murid atau murid dengan guru untuk menganalisis, memecahkan masalah, meggali, memperdebatkan topik atau permasalahan tertentu, metode diskusi akan sangat cocok diterapkan untuk memecahkan masalah khususnya soal yang berupa studi kasus. Menurut Cahyo (2012) metode discovery learning adalah pembelajaran yang dirancang sedikian rupa agar murid dapat menemukan suatu konsep dalam memecahkan suatu masalah sehingga mengarahkan keaktifan murid, mencari, mengolah dan meyelesaikan masalah.

Metode yang digunakan sebagai solusi dalam menyelesaikan masalah tersebut menurut peneliti adalah metode discovery learning berbasis alat peraga. Metode ini akan melibatkan secara maksimal seluruh kemampuan murid. Murid dapat mencari dan menemukan sesuatu cara sistematis, logis, analitis sehingga mereka dapat merumuskan sendiri penemuannya melalui alat peraga yang dikembangkan oleh guru.

Metode discovery learning menurut Sulistyowati, Widodo, dan Sumarni, (2012) merupakan salah satu metode yang bertujuan melatih murid untuk menemukan konsep mandiri. Menurut Rohim, Susanto dan Ellianawati (2012) mengemukakan bahwa metode discovery learning merupakan suatu metode yang dapat membantu murid memperoleh dua kriteria penting dalam pembelajaran aktif yaitu membangun pengetahuan untuk membuat pengertian dari informasi baru dan mengintegrasikan informasi baru sampai ditemukan pengetahuan yang tepat. Menurut Widhiyantoro, Indrowati dan Probosari (2012), langkah-langkah operasional dalam mengaplikasikan metode discovery learning di kelas yaitu: stimulation (pemberian rangsangan), problem statement (pertanyaan/identifikasi masalah), data collection (pengumpulan data), data processing (pengolahan data), verification (pembuktian) dan generalization (menarik kesimpulan/generalisasi). Memilih suatu metode pembelajaran tidaklah cukup dalam merancang pembelajaran tetapi dibutuhkan 
juga media atau alat peraga agar memudahkan murid memahami materi yang diajarkan.

Sanjaya (2008) menyatakan bahwa media adalah alat untuk memberi perangsang bagi murid supaya terjadi proses belajar. Menurut Sundayana (2013) mengatakan bahwa media apabila dipahami secara garis besar adalah manusia, materi atau kejadian yang membangun kondisi yang membuat murid mampu memperoleh pengetahuan, keterampilan, atau sikap dalam pengetahuan ini, guru, buku teks dan lingkungan sekolah merupakan media. Menurut Sugiarto (2010) pemanfaatan media/alat peraga yang dilakukan secara benar akan memberikan kemudahan bagi murid untuk membangun sendiri pengetahuan yang sedang dipelajarinya. Menurut Widyaningsih dan Yusuf (2015) alat peraga sederhana dapat dibuat dengan memanfaatkan benda-benda sederhana yang ada disekitar sekolah, bahkan barang-barang bekas sekalipun sehingga dalam pembuatannya tidak membutuhkan biaya serta waktu berlebih karena selain bahan-bahannya dapat dengan mudah diperoleh kita juga dapat memanfaatkan barang-barang bekas tak terpakai di sekitar rumah dan sekolah. Media atau alat peraga yang dikembangkan dalam penelitian ini adalah tangram matematika dan geoboard. Hasil pengembangan alat peraga tersebut diberi nama alat peraga GRANDER.

GRANDER merupakan alat peraga gabungan dari tangram matematika dan geoboard. Menurut Khorina (2016) tangram merupakan permainan puzzle dari China, terdiri dari tujuh potong bangun datar (lima segitiga dengan ukuran yang berbeda, satu persegi dan satu jajar genjang) yang bisa disusun menjadi berbagai bentuk baru tanpa tumpang tindih dengan macam-macam variasi yang mampu membantu memahami konstruksi geometri berupa bangun datar. Kelebihan dari tangram matematika adalah menumbuhkan minat belajar murid karena pelajaran menjadi lebih menarik, memperjelas makna bahan pelajaran sehingga murid lebih mudah memahaminya, metode mengajar akan lebih bervariasi sehingga murid tidak akan mudah bosan, membuat murid lebih aktif melakukan kegiatan belajar seperti: mengamati, melakukan dan mendemonstrasikan (Khoirina, 2016). Menurut Husnaya (2018) geoboard adalah suatu papan berpaku yang dapat digunakan untuk media dalam materi geometri sehingga dalam mempelajari materi bangun datar, media ini cocok digunakan sebagai penunjang dalam mengajar. Kelebihan dari geoboard adalah sebagai alat bantu guru, pembuatan media mudah, murid mudah mengelompokkan bentuk bangun datar, murid lebih terampil, tahan lama dan bahannya mudah didapat (Nisa dan Bustoniyah, 2015). Kekurangan dari geoboard adalah banyak menuntut peran guru, media geoboard sangat berbahaya bagi anak karena terdapat paku yang tajam, butuh banyak waktu dalam pembuatannya, perlu kesediaan untuk berkorban secara materil (Lastrijanah, Prasetyo, dan Mawardini, 2017).

Sejalan dengan penelitian Fusiari (2016) bahwa Perangkat pembelajaran model discovery learning pada materi pokok optik layak digunakan, keterlaksanaan pembelajaran pada pembelajaran model discovery learning telah dilaksanakan dengan baik sesuai dengan proses belajar mengajar yang telah direncanakan, menjadikan murid aktif dalam proses pembelajaran, hasil belajar murid mencapai ketuntasan klasikal. Selanjutnya menurut Supriyanto (2014) bahwa penerapan discovery learning pada mata pelajaran matematika murid sekolah dasar dapat meningkatkan hasil belajar mereka karena melalui penerapan discovery learning, murid memiliki pengalaman karena mereka melakukan sesuatu percobaan yang memungkinkan mereka untuk menemukan konsep atau prinsip-prinsip matematika bagi diri mereka sendiri. Menurut Rahman (2017) bahwa model pembelajaran discovery learning dapat mendorong kemampuan berpikir kreatif murid. Hal ini sejalan pula dengan penelitian yang dilakukan oleh Suliyati, Yusuf dan Widyaningsih (2018) bahwa penggunaan alat peraga sederhana dalam pembelajaran dapat meningkatkan hasil belajar murid karena melalui alat peraga sederhana tersebut murid dapar bereksplorasi dan menemukan suatu 
konsep dengan cara melakukan sendiri proses penemuan. Menurut Ginting dan Surya (2017) bahwa penggunaan alat peraga dapat meningkatkan hasil belajar murid. Selanjutnya menurut Rahmani dan Widyasari (2018) bahwa media tangram dapat meningkatan kemampuan pemecahan masalah matematika murid. Menurut Damiati, Rufi'i, dan Danu (2018) bahwa penggunaan media tangram dihasilkan dalam pengembangan produk tepat dan baik digunakan oleh murid dalam kegiatan belajar. Selanjutnya Menurut Husnaya (2018) model pembelajaran think pair share berbantuan media geoboard sangat efektif untuk meningkatkan hasil belajar murid. Menurut Saidu dan Bunyamin (2016) bahwa penggunaan geoboard menjadikan pelajaran lebih bermakna.

Tujuan penelitian ini untuk mengetahui validitas, praktikalitas dan efektivitas perangkat pembelajaran matematika menggunakan metode discovery learning berbasis GRANDER pada murid kelas VI SD. Manfaat penelitian ini adalah Perangkat pembelajaran yang telah dikembangkan, diharapakan dapat membantu murid dalam proses belajar sehingga murid dalam memahami masalah-masalah yang harus diselesaikan yang sesuai dengan tuntutan suatu materi pembelajaran.

\section{METODE}

Penelitian ini merupakan penelitian pengembangan dengan model pengembangan 4-D. Model ini dikembangkan oleh Thagarajan. Model pengembangan 4-D terdiri atas 4 tahap utama yaitu: define (pendefinisian), design (perencanaan), develop (pengembangan) dan disseminate (penyebaran), atau diadaptasi model 4-P, yaitu pendefinisian, perancangan, pengembangan dan penyebaran (Sani, Manurung, Suswanto dan Sudiran 2018). Namun dalam penelitian ini hanya sampai pada tahap pengembangan. Tahap pendefinisian bertujuan untuk menetapkan dan mendefinisikan syarat-syarat pembelajaran. Dalam menentukan dan menetapkan syarat-syarat pembelajaran diawali dengan analisis tujuan. Tahap ini meliputi analisis awal, analisis murid, analisis konsep, analisis tugas, spesifikasi tujuan. Tahap perancangan bertujuan untuk menyiapkan prototipe perangkat pembelajaran matematika menggunakan metode discovery learning berbasis GRANDER. Tahap ini meliputi penyusunan tes, pemilihan alat peraga, pemilihan format, dan rancangan awal. Tahap pengembangan bertujuan untuk menghasilkan perangkat pembelajaran yang sudah direvisi berdasarkan masukan dari para pakar maupun setelah dilakukan uji coba. Tahap ini meliputi validasi, dan uji coba terbatas.

Teknik pengumpulan data dalam penelitian ini adalah data dikumpulkan dengan menggunakan lembar validasi, data dikumpulkan dengan menggunakan angket respon murid, data dikumpulkan dengan menggunakan lembar observasi keterlaksanaan perangkat pembelajaran, data dikumpulkan dengan menggunakan instrumen hasil belajar murid, data dikumpulkan dengan menggunakan lembar observasi aktivitas murid dan data dikumpulkan dengan menggunakan lembar observasi kemampuan guru dalam mengelola pembelajaran. Teknis analisi data penelitian ini adalah sebagai berikut.

\section{Analisis Validitas}

Untuk mengetahui validitas perangkat pembelajaran dan instrumen penelitian dilakukan uji validasi sesuai dengan penilaian para ahli. Kegiatan yang dilakukan untuk analisis validasi menurut Hobri (2010) adalah sebagai berikut.

Pertama melakukan rekapitulasi hasil penilaian ahli ke dalam tabel yang meliputi: aspek (Ai), kriterian (Ki), hasil penialain validator (vji). Kedua mencari rerata hasil penilaian ahli untuk setiap kriteri dengan rumus:

$$
K_{i}=\frac{\sum_{J=1}^{n} V_{i j}}{n}
$$

Keterangan:

$K_{i}=$ rerata kriteria ke-i 
$V_{i j}=$ skor hasil penilaian terhadap kriteria ke-i oleh penilai ke-j

$\mathrm{n}=$ banyaknya penilai

Tahap ketiga mencari rerata tiap aspek dengan rumus:

$$
A_{i}=\frac{\sum_{J=1}^{n} K_{i j}}{n}
$$

Keterangan:

$A_{i}=$ rerata aspek ke-i

$K_{i j}=$ rerata untuk aspek ke-i kriteria ke-j

$\mathrm{n} \quad$ = banyaknya kriteria dalam aspek ke-

Selanjuntnya mencari rerata total $(X)$ dengan rumus

$$
X=\frac{\sum_{J=1}^{n} A_{i}}{n}
$$

Keterangan:

$X=$ rerata total

$A_{i} \quad=$ rerata aspek ke-1

$\mathrm{n} \quad$ = banyaknya aspek

Adapun kriteria kategori validitas dapat dilihat pada tabel berikut.

Tabel 1. Kriteria Kategori Validitas

\begin{tabular}{ll}
\hline Interval Skor & Kategori Validitas \\
\hline $3,5 \leq X \leq 4$ & Sangat Valid \\
\hline $2,5 \leq X<3,5$ & Valid \\
\hline $1,5 \leq X<2,5$ & Cukup Valid \\
\hline$X<1,5$ & Tidak Valid \\
\hline & Sumber: Nurdin (2007)
\end{tabular}

Selanjutnya, pernyataan yang dinyatakan valid dilakukan analisis reliabilitas. Pengujian reliabilitas tersebut menggunakan rumus Alpha sebagai berikut.

$$
r_{11}=\left(\frac{k}{k-1}\right)\left(1-\frac{\sum \sigma_{b}^{2}}{\sigma_{t}^{2}}\right)
$$

Sumber: Arikunto (2006)

Keterangan:

r11 : Reliabilitas instrumen

$\mathrm{k} \quad$ : Banyaknya butir pernyataan

$\sum \sigma \mathrm{b} 2$ : Jumlah variansi butir

$\sum \sigma \mathrm{t} 2$ : Variansi total
Nilai reliabilitas yang diperoleh selanjutnya dikonsultasikan dengan nilai reliabilitas tabel. Instrumen dikatagorikan reliabel jika diperoleh nilai reliabilitas hitung lebih besar daripada reliabilitas tabel.

\section{Analisis Praktikalitas}

Untuk melakukan analisis kepraktisan perangkat pembelajaran ada dua indikator yaitu respon murid dan keterlaksanaan perangkat pembelajaran. Respon murid dilakukan dengan menentukan skor rata-rata dari data pengisian angket respon murid. Kemudian mengkonversikan skor yang telah diperoleh menjadi nilai kualitatif skala lima sesuai kriteria penilaian dalam tabel berikut.

Tabel 2. Pedoman Pengubahan Data Kuantitatif Menjadi Data Kualitatif Angket Respon guru dan murid

\begin{tabular}{ll}
\hline Interval & Kriteria \\
\hline$X>3,4$ & Sangat baik \\
\hline $2,8<X \leq 3,4$ & Baik \\
\hline $2,2<X \leq 2,8$ & Cukup \\
\hline $1,6<X \leq 2,2$ & Kurang \\
\hline$X \leq 1,6$ & Sangat Kurang \\
\hline & Sumber: Yamsari (2010)
\end{tabular}

Produk yang dikembangkan dikatakan layak berdasarkan aspek kepraktisan, jika kriteria yang dicapai minimal adalah tingkat baik.

Indikator kedua untuk menentukan kepraktisan perangkat pembelajaran adalah menghitung keterlaksanaan perangkat pembelajaran dengan cara sebagai berikut. Tahap pertama mencari rata-rata untuk setiap aspek pengamatan setiap pertemuan

$$
A_{m i}=\frac{\sum_{j=1}^{n} K_{i j}}{n}
$$

Sumber: Nurdin (2007)

\section{Keterangan:}

$\mathrm{A}_{\mathrm{mi}}=$ rata-rata aspek $\mathrm{ke}-\mathrm{i}$

$\mathrm{K}_{\mathrm{ij}}=$ rata-rata aspek ke $-\mathrm{i}$ kriteri ke $-\mathrm{j}$

$\mathrm{n}$ = banyaknya kriteria dalam aspek ke $-\mathrm{i}$ 
Tahap kedua mencari rata-rata tiap aspek pengamatan untuk setiap kali pertemuan dengan rumus:

$$
A_{i}=\frac{\sum_{m=1}^{t} A_{m i}}{t}
$$

\section{Keterangan:}

$A_{i}=$ Rata-rata nilai aspek ke - $\mathrm{i}$

$A_{m i}=$ Rata-rata aspek ke - i kriteria ke - $\mathrm{j}$

$\mathrm{t}=$ Banyaknya pertemuan

Tahap ketiga menentukan kategori keterlaksanaan setiap aspek atau keseluruhan aspek dengan mencocokkan rata-rata setiap aspek ( $\mathrm{Ai}$ ) atau rata-rata total $(\mathrm{x})$ dengan kategori yang telah ditetapkan.

Kategori keterlaksanaan setiap aspek atau keseluruhan aspek keterlaksanaan perangkat dapat dilihat pada tabel 3 di bawah ini.

Tabel 3. Kategori Keterlaksanaan Perangkat Pembelajaran

\begin{tabular}{ll}
\hline Interval Nilai & $\begin{array}{l}\text { Kategori } \\
\text { keterlaksanaan }\end{array}$ \\
\hline $1,5 \leq \mathrm{M}<2,0$ & Terlaksana Seluruhnya \\
\hline $0,5 \leq \mathrm{M}<1,5$ & Terlaksana Sebagian \\
\hline $0,0 \leq \mathrm{M}<0,5$ & Tidak Terlaksana \\
\hline
\end{tabular}

Sumber: Nurdin (2007)

\section{Keterangan: \\ $\mathrm{M}=\mathrm{At}$, Untuk mencari keterlaksanaan setiap perangkat \\ $\mathrm{M}=\mathrm{x}$, Untuk mencari keterlaksaan keseluruhan aspek}

Kriteria yang digunakan untuk memutuskan bahwa perangkat pembelajaran memiliki derajat keterlaksanaan yang memadai adalah $\mathrm{x}$ dan At minimal berada pada kategori terlaksana sebagian.

\section{Analisis Efektivitas}

Perangkat pembelajaran dikatakan efektif jika tiga indikator tercapai yaitu $85 \%$ murid tuntas, $85 \%$ murid aktif dan kemampuan guru dalam mengelola pembelajaran berada dalam kategori tinggi.
Indikator pertama adalah hasil belajar. Cara menentukan ketuntasan hasil belajar adalah Menghitung skor murid dari tes hasil belajar, kemudian menghitung banyaknya murid yang tuntas atau mendapatkan skor minimal sesuai KKM. Selanjunta menghitung persentase ketuntasan belajar (p) sebagai berikut.

$$
\mathrm{p}=\frac{n t}{n} \times 100 \%
$$

\section{Keterangan:}

$\mathrm{p}=$ persentase ketuntasan belajar

$\mathrm{nt}=$ banyaknya murid yang tuntas

$\mathrm{n}$ = banyaknya murid yang mengikuti tes.

Kemudian, kriteria kentuntasan mengacu pada tabel 4 berikut.

Tabel 4 Kriteria Ketuntasan Belajar Klasikal

\begin{tabular}{ll}
\hline Persentase skor (\%) & Kriteria \\
\hline$p>80$ & Sangat baik \\
\hline $60<p \leq 80$ & Baik \\
\hline $40<p \leq 60$ & Cukup \\
\hline $20<p \leq 40$ & Kurang \\
\hline$p \leq 20$ & Sangat Kurang \\
\hline & Sumber: Widoyoko (2011)
\end{tabular}

Keterangan:

$p=$ persentase ketuntasan belajar

Produk yang dikembangkan dikatakan layak berdasarkan aspek keefektifan, jika kriteria yang dicapai minimal $85 \%$ murid tuntas dan berada dalam kategori sangat baik.

Indikator Kedua adalah aktivitas murid. Perangkat pemebalajaran dikatakan efektif jika $85 \%$ murid aktif dalam proses pembelajaran. Adapun aktivitas yang dinilai adalah memperhatikan demonstrasi, melakukan percobaan, mengajukan pertanyaan kepada guru atau murid, diskusi kelompok, mendengarkan penyajian/percakapan, mengerjakan soal-soal, dan menyimpulkan pembelajaran.

Skor maksimal yang dapat diperoleh setiap murid yaitu 28 poin (7 x 4 poin). Dari skor yang diperoleh oleh setiap murid tersebut, selanjutnya dirata-ratakan untuk memperoleh 
skor keseluruhan. Berikut kategori aktivitas murida dapat dilihat pada tabel 5 sebagai berikut.

Tabel 5. Kriteria Interpretasi Skor

\begin{tabular}{ll}
\hline Persentase (\%) & Kriteria \\
\hline $86-100$ & Sangat Tinggi \\
\hline $76-85$ & Tinggi \\
\hline $60-75$ & Sedang \\
\hline $0-59$ & Rendah \\
\hline & Sumber: Purwanto (2012)
\end{tabular}

Dikatakan efektif jika aktivitas murid berada dalam kategori tinggi atau $85 \%$ murid aktif dalam proses pembelajaran.

Indikator ketiga adalah kemampuan guru dalam mengelola pembelajaran. Penilaian yang dilakukan untuk mengetahui kemampuan guru dalam mengelola kegiatan berdasarkan hasil observasi kegiatan guru. Tingkat kemampuan guru tiap pertemuan dihitung dengan cara menjumlah nilai tiap aspek kemudian membaginya dengan banyak aspek yang dinilai. Aspek yang dimaksud meliputi kegiatan awal, kegiatan inti, kegiatan akhir dan pengamatan suasana kelas yang diukur dengan instrumen lembar observasi kemapuan guru mengelola pembelajaran.

Untuk pengategorian kemampuan guru tersebut digunakan kategori pada tabel berikut.

Tabel 6 Kategori Kemampuan Guru dalam Mengelola Pembelajaran Menggunakan Metode Discovery Learning Berbasis GRANDER

\begin{tabular}{cl}
\hline Kemampuan Guru (KG) & Kriteria \\
\hline $3,5 \leq \mathrm{KG} \leq 4,0$ & Sangat Tinggi \\
\hline $2,5 \leq \mathrm{KG}<3,5$ & Tinggi \\
\hline $1,5 \leq \mathrm{KG}<2,5$ & Sedang \\
\hline $\mathrm{KG}<1,5$ & Rendah \\
\hline & Sumber: Nurdin (2007)
\end{tabular}

Kriteria yang digunakan untuk menetapkan bahwa kemampuan guru mengelola pembelajaran menggunakan metode discovery learning berbasis GRANDER memadai adalah KG minimal berada dalam kategori "tinggi" berarti penampilan guru dapat dipertahankan.

\section{HASIL DAN PEMBAHASAN}

\section{Hasil Validitas Perangkat Pembelajaran, Alat Peraga Dan Instrumen Penelitian}

Hasil validitas dan reliabilitas perangkat pembelajaran dan alat peraga dapat dilihat pada tabel 7 berikut.

Tabel 7. Hasil Validitas Perangkat Pembelajaran dan Alat Peraga GRANDER

\begin{tabular}{lcc}
\hline $\begin{array}{l}\text { Perangkat } \\
\text { pembelajaran dan Alat } \\
\text { Paraga GRANDER }\end{array}$ & Validitas & Reliabilitas \\
\hline Silabus & 3,6 & 0,9998 \\
\hline RPP & 3,6 & 0,9998 \\
\hline Buku Murid & 3,7 & 0,9998 \\
\hline LKM & 3,8 & 0,996 \\
\hline Instrumen Penilaian & 3,6 & 0,9999 \\
\hline Hasil Belajar & 3,6 & 0,9999 \\
\hline Alat Peraga GRANDER & &
\end{tabular}

Berdasarkan tabel di atas dapat disimpulkan bahwa perangkat pembelajaran dan alat peraga valid dengan kategori sangat valid. Adapun hasil reliabilitas perangkat pembelajaran dan alat peraga dinyatakan reliabel karena t hitung lebih besar dari t tabel dengan nilai $\mathrm{n} 70$ dan nilai t tabel untuk taraf signifikansi $5 \%$ adalah 0,2352 . Adapun validitas dan reliabilitas insrumen penelitian dapat dilihat pada tabel 8 berikut.

Tabel 8 Hasil validitas dan reliabilitas insrumen penelitian

\begin{tabular}{lcc}
\hline Instrumen Penelitian & $\begin{array}{c}\text { Rerata } \\
\text { Validitas }\end{array}$ & $\begin{array}{c}\text { Rerata } \\
\text { Reliabilitas }\end{array}$ \\
\hline Angket Respon Murid & 3,4 & 0,9994 \\
\hline $\begin{array}{l}\text { Lembar Pengamatan } \\
\text { Keterlaksanaan }\end{array}$ & 3,7 & 0,9999 \\
$\begin{array}{l}\text { Perangkat } \\
\text { Pembelajaran }\end{array}$ & & \\
\hline $\begin{array}{l}\text { Lembar Pengamatan } \\
\text { Aktivitas Murid }\end{array}$ & 3,8 & 1 \\
\hline $\begin{array}{l}\text { Lembar Pengamatan } \\
\text { Kemampuan Guru } \\
\text { dalam Mengelola } \\
\text { Pembelajaran }\end{array}$ & 3,8 & 1 \\
\hline
\end{tabular}

Berdasarkan tabel di atas diperoleh hasil angket respon murid diperoleh rata-rata validasi 3,4 dengan kategori valid, lembar keterlaksanaan perangkat pembelajaran 
diperoleh rata-rata 3,7 kategori sangat valid, lembar pengamatan aktivitas murid diperoleh rata-rata 3,8 kategori sangat valid dan lembar pengamatan kemampuan guru dalam pengelola pembelajran diperoleh rata-rata 3,8 kategori sangat valid. Adapun hasil reliabilitas instrumen penelitian dinyatakan reliabel karena t hitung lebih besar dari t tabel dengan nilai t tabel untuk taraf signifikansi $5 \%$ adalah 0,2352 .

Sejalan dengan penelitian Arifin (2017) instrumen memiliki peranan yang sangat penting karena dengan adanya instrumen mutu suatu penelitian dapat diketehui. Jika instrumen yang dibuat memiliki kriteria yang baik maka mutu penelitian juga baik begitupun sebaliknya. Menurut Khaeruddin (2015) salah satu cara untuk memperbaiki proses pembelajaran yang paling efektif ialah dengan jalan mengevaluasi tes hasil belajar yang di peroleh dari proses pembelajaran itu sendiri. Dengan kata lain, hasil tes itu kita olah sedemikian rupa sehingga dari hasil pengolahan itu dapat di ketahui komponenkomponen manakah dari proses pembelajaran itu yang masih lemah. Menurut Fitri (2017) semakin tinggi nilai validitas dan reliabilitas maka semakin jitu data yang diperoleh. Sehingga kualitas instrumen penelitian sangat menentukan hasil penelitian yang akan dicapai.

\section{Hasil Praktikalitas Perangkat Pembelajaran}

Indikator praktikalitas perangkat pembelajaran adalah respon murid dan keterlaksanaan perangkat pembelajaran. Praktikalitas perangkat pembelajaran dihitung masing-masing sekolah yang diteliti.

Tabel 9 Hasil Praktikalitas Perangkat Pembelajaran

\begin{tabular}{lll}
\hline Tempat Penelitian & $\begin{array}{l}\text { Respon } \\
\text { Murid }\end{array}$ & $\begin{array}{l}\text { Keterlaksanaan } \\
\text { Perangkat } \\
\text { Pembelajaran }\end{array}$ \\
\hline $\begin{array}{l}\text { Kelas VI A SD Inpres } \\
\text { Minasa Upa }\end{array}$ & 3,3 & 1,9 \\
\hline $\begin{array}{l}\text { Kelas VI B SD Inpres } \\
\text { Karunrung }\end{array}$ & 3,7 & 2 \\
\hline $\begin{array}{l}\text { Kelas VI A SD Inpres } \\
\text { Minasa Upa 1 }\end{array}$ & 3,2 & 1,9 \\
\hline
\end{tabular}

Berdasarkan hasil analisis data bahwa respon murid di kelas VI A SD Inpres Minasa Upa diperoleh rata-rata 3,3 dengan kategori baik, respon murid di kelas VI B SD Inpres Karunrung diperoleh rata-rata 3,7 dengan kategori sangat baik, respon murid di kelas VI A SD Inpres Minasa Upa 1 diperoleh rata-rata 3,2 dengan kategori baik.

Keterlaksanaan perangkat pembelajaran di kelas VI A SD Inpres Minasa Upa diperoleh rata-rata 1,9 dengan kategori terlaksana seluruhnya, keterlaksanaan perangkat pembelajaran di kelas VI B SD Inpres Karunrung diperoleh rata-rata 2 dengan kategori terlaksana seluruhnya dan keterlaksanaan perangkat pembelajaran di kelas VI A SD Inpres Minasa Upa 1 diperoleh rata-rata 1,9 dengan kategori terlaksana seluruhnya.

Sehingga dapat disimpulkan bahwa perangkat pembelajaran praktis karena semua indikator tercapai. Sejalan dengan penelitian Ramadhani (2016) bahwa perangkat pembelajaran dikatakan praktis jika murid memberikan respon berada dalam kategori baik dan hasil penelitiannya menunjukkan bahwa respon murid berada dalam ketegori baik. Sehingga respon murid sangat menentukan kepraktisan perangkat pembelajaran berbasis GRANDER yang dikembangkan karena murid sebagai pengguna dari produk tersebut. Selanjutnya menurut Fusiari (2016) bahwa perangkat pembelajaran model discovery learning pada materi pokok optik layak digunakan, keterlaksanaan pembelajaran pada pembelajaran model discovery learning telah dilaksanakan dengan baik sesuai dengan proses belajar mengajar yang telah direncanakan, menjadikan murid aktif dalam proses pembelajaran, hasil belajar murid mencapai ketuntasan klasikal.

\section{Hasil Efektivitas Perangkat Pembelajaran}

Indikator efektivitas perangkat pembelajaran adalah hasil belajar, aktivitas murid dan kemampuan guru dalam mengelola pembelajaran. Efektivitas perangkat pembelajaran dihitung masing-masing sekolah yang diteliti. 
Tabel 10 Hasil Efektivitas Perangkat

Pembelajaran

\begin{tabular}{lcccc}
\hline Tempat & HB KD & HB KD & AM & KG \\
Penelitian & $\mathbf{3 . 5}$ & $\mathbf{4 . 5}$ & & \\
\hline $\begin{array}{l}\text { Kelas VI A SD } \\
\text { Inpres Minasa }\end{array}$ & $95 \%$ & $100 \%$ & $88 \%$ & 3,7 \\
Upa & & & & \\
\hline $\begin{array}{l}\text { Kelas VI B SD } \\
\text { Inpres }\end{array}$ & $92 \%$ & $100 \%$ & $89 \%$ & 3,9 \\
Karunrung & & & & \\
\hline $\begin{array}{l}\text { Kelas VI A SD } \\
\text { Inpres Minasa }\end{array}$ & $92 \%$ & $100 \%$ & $89 \%$ & 3,8 \\
Upa 1 & & & & \\
\hline
\end{tabular}

\section{Keterangan:}

HB KD 3.5 : Hasil Belajar Kompetensi Dasar 3.5

HB KD 4.5 : Hasil Belajar Kompetensi Dasar 4.5

AM : Aktivitas Murid

KG : Kemampuan guru dalam mengelola pembelajaran

Berdasarkan tabel di atas menunjukan bahwa hasil belajar murid di kelas VI A SD Inpres Minasa Upa 95\% murid tuntas di KD 3.5 dan $100 \%$ murid tuntas di KD 4.5, hasil belajar murid di kelas VI B SD Inpres Karunrung 92\% murid tuntas di KD 3.5 dan $100 \%$ murid tuntas di KD 4.5, hasil belajar murid di kelas VI A SD Inpres Minasa Upa 92\% murid tuntas di KD 3.5 dan 100\% murid tuntas di KD 4.5.

Hasil aktivitas murid diperoleh bahwa aktivitas murid di kelas VI A SD Inpres Minasa Upa menunjukkan 88\% murid aktif dalam proses pembelajaran, di kelas VI B SD Inpres Karunrung menunjukkan $89 \%$ murid aktif dalam proses pembelajaran, aktivitas murid di kelas VI A SD Inpres Minasa Upa 1 menunjukkan $89 \%$ murid aktif dalam proses pembelajaran.

Hasil kemampuan guru dalam mengelola pembelajaran diperoleh kemampuan guru dalam mengelola pembelajaran di kelas VI A SD Inpres Minasa Upa diperoleh rata-rata 3,7 dengan kategori sangat tinggi, kemampuan guru dalam mengelola pembelajaran di kelas VI B SD Inpres Karunrung diperoleh rata-rata 3,9 dengan kategori sangat tinggi dan kemampuan guru dalam mengelola pembelajaran di kelas VI A SD Inpres Minasa
Upa 1 diperoleh rata-rata 3,8 dengan kategori sangat tinggi.

Sehingga dapat disimpulkan bahwa perangkat pembelajaran efektif karena semua indikator tercapai. Sejalan dengan penelitian Rahman (2017) bahwa model pembelajaran discovery learning dapat mendorong kemampuan berpikir kreatif murid. Hal ini sejalan pula dengan penelitian yang dilakukan oleh Suliyati, Yusuf dan Widyaningsih (2018) bahwa penggunaan alat peraga sederhana dalam pembelajaran dapat meningkatkan hasil belajar murid karena melalui alat peraga sederhana tersebut murid dapar bereksplorasi dan menemukan suatu konsep dengan cara melakukan sendiri proses penemuan. Selanjutnya menurut Wahyudi (2015) bahwa pembelajaran discovery learning meningkatkan aktivitas murid dalam pembelajaran, membuat murid semakin bersemangat dalam belajar, dan meningkatkan hasil belajar murid. Selanjutnya menurut Walker (2018) pembelajaran melalui diskusi kelompok dapat meningkatkan aktivitas murid dalam belajar. Sehingga sangat penting dalam pemilihan metode pembelajaran yang digunakan dalam proses pembelajaran karena sangat menentukan ketercapaian aktivitas murid dalam proses pembelajaran.

\section{KESIMPULAN}

Berdasarkan hasil pengembangan dan uji coba produk terkait perangkat pembelajaran matematika menggunakan metode discovery learning berbasis GRANDER, maka dapat disimpulkan sebagai berikut: (1) Perangkat pembelajaran, alat peraga GRANDER dan instrumen penelitian berupa silabus, Rencana Pelaksanaan Pembalajarn (RPP), buku murid, Lembar Kegiatan Murid (LKM), instrumen penilaian hasil belajar, angket respon murid, lembar pengamatan keterlaksanaan perangkat pembelajaran dan lembar pengamatan kemampuan guru dalam mengelola pembelajaran dinyatakan valid dan reliabel; (2) Perangkat pembelajaran berbasis GRANDER dinyatakan praktis karena dua indikator tercapai yaitu respon murid dan 
keterlaksanaan perangkat pembelajaran; (3) Perangkat pembelajaran berbasis GRANDER dinyatakan efektif karena tiga indikator tercapai yaitu hasil belajar, aktivitas murid dan kemampuan guru dalam mengelola pembelajaran.

\section{Daftar Pustaka}

[1] Abduh, M. (2015). Pengembangan Perangkat Pembelajaran Tematik Integratif Berbasis Sosiokultural di Sekolah Dasar. Jurnal Penelitian Ilmu Pendidikan Universitas Negeri Yogyakarta, 8(1).

[2] Aqib, Z. (2014). Model-model, Media dan Strategi Pembelajaran Kontekstual (Inovatif). Bandung: Yrama Widya.

[3] Arifin, Z. (2017). Kriteria Instrumen dalam Suatu Penelitian. Jurnal THEOREMS, 2(1).

[4] Arikunto, S. (2006). Prosedur Penelitian: Suatu Pendekatan Praktik. Jakarta: Rineka Cipta.

[5] Cahyo, A. N. (2012). Teori-teori Belajar Mengajar. Jogjakarta: Diva Press.

[6] Damiati, M., Rufi'i., \& Danu, R. (2018). The Elaboration of Tangram Media with a Scientific Approach to Social Studies Learning in Elementary School. International Journal for Innovation Education and Research, 6(12).

[7] Fitri. (2017). Analisis Validitas dan Reliabilitas Instrumen Kerja Akuntan Menggunakan Pendekatan Rach Model. Jurnal Ilmiah Akuntansi Peradaban, 3(1).

[8] Fusiari, A. I. (2016). Pengembangan Perangkat Pembelajaran Model Discovery Learning pada Materi Pokok Optik di SMP. Jurnal Inovasi Pendidikan Fisika, 5(1).

[9] Fusiari, A. I. (2016). Pengembangan Perangkat Pembelajaran Model Discovery Learning pada Materi Pokok Optik di SMP. Jurnal Inovasi Pendidikan Fisika, 5(1).

[10] Gintinga, I. N. B., Surya, E. Use of Figure Tools to Increase Mathematics Result Learning Student Class V Prymary School 101796 Patumbak. International Journal of Sciences: Basic and Applied Research, 34(1).
[11] Hidayat, S. (2013). Pengembangan Kurikulum Baru. Bandung: Remaja Rosdakarya Offset.

[12] Hobri. (2010). Metodologi Penelitian Pengembangan (Aplikasi pada Penelitian Pendidikan Matematika). Jember: Pena Salsabila.

[13] Husnaya, A. I. (2018). Keefektifan Model Pembelajaran Kooperatif Tipe Think Pair Share pada Materi Bangun Datar Berbantu Media Geoboard terhadap Pemahaman Konsep dan Motivasi Belajar Murid Kelas IV SDN Troso 06 Pecangaan Jepara. Jurnal Lensa Pendas, 3(2).

[14] Ibrahim, (2003). Pengembangan Perangkat Pembelajaran. Jakarta: Dirjen Dikdasmen.

[15] Kemendikbud. (2016). Peraturan Menteri Pendidikan dan Kebudayaan Nomor 22 Tahun 2016 tentang Standar Proses Pendidikan Dasar dan Menengah. Jakarta: Kemendikbud

[16] Khaerudiin. (2017). Kualitas Instrumen Tes Hasil Belajar. Jurnal Madaniyah, 2(9).

[17] Khoirina, Z. (2016). Pengaruh Media Tangram Terhadap Hasil Belajar Tema Lingkungan Siswa Kelas II Madrasah Ibtidaiyah Da'watul Khoir Nganjuk. Jurnal PGSD, 4(2).

[18] Lastrijanah, Prasetyo, T., \& Mawardini, A. (2017). Pengaruh Media Pembelajaran Geoboard terhadap Hasil Belajar Siswa. Jurnal Didaktika Tauhidi, 4(2).

[19] Nasution, M. K. (2017). Penggunaan Metode Pembelajaran Dalam Peningkatan Hasil Belajar Siswa. Jurnal Ilmiah Bidang Penddidikan, 11(1).

[20] Nisa, T. F., Bustoniyah, U. (2015). Efektivitas Penggunaan Geoboard Bangun Datar Dalam Pembelajaran Matematika. Jurnal Apotema, 1(2).

[21] Nurdin. (2007). Model Pembelajaran Pembelajaran Matematika Yang Menumbuhkan Kemempuan Metakognitif Untuk Menguasi Bahan Ajar. Disertasi. Surabaya: PPs UNESA.

[22] Purwanto. (2012). Metodologi Penelitian Kuantitatif untuk Psikologi dan Pendidikan. Yogyakarta: Pusaka Pelajar Offset. 
[23] Rahman, M. H. (2017). Using Discovery Learning to Encourage Creative Thinking. International Journal of Social Sciences and Educational Studies, 4(2), s. 98, doi: 10.23918/ijsses.v4i2sip98.

[24] Rahmani, W., Widyasari, N. (2018). Meningkatkan Kemampuan Pemecahan Masalah Matematis Siswa Melalui Media Tangram. Jurnal Pendidikan Matematika, 4(1)

[25] Ramadhani, R. (2016). Pengembangan Perangkat Pembelajaran Matematika yang Berorientasi Pada Model Problem Based Learning. Jurnal Matematika Kreatif Inovatif, 7(2).

[26] Rohim, F., Susanto, H., \& Ellianawati. (2012). Penerapan Model Discovery Terbimbing pada Pembelajaran Fisika untuk Meningkatkan Kemampuan Berpikir Kreatif. Unnes Physic Education Journal, 1(1), 1-5.

[27] Saidu, S., Bunyamin, S. (2016). Effects Of Geoboard And Geographical Globe On Senior Secondary School Students' Performance In Mathematics In Kaduna State. Journal of Science, Technology \& Education (JOSTE), 4(1).

[28] Sani, R. A., Manurung, S. R., Suswanto, H., Sudiran. (2018). Penelitian Pendidikan. Tangerang: Tira Smart.

[29] Sanjaya, W. (2008). Perencanaan dan Desain Sistem Pembelajaran. Jakarta: Kencana.

[30] Sardiman. (2011). Interaksi dan Motivasi Belajar Mengajar. Jakarta: Rajawali Pers.

[31] Sugiarto. (2010). Workshop Pendidikan Matematika 1. Jurusan Matematika FMIPA. Semarang: UNNES

[32] Suliyati, M., Yusuf, I., Widyaningsih, S. W. (2018). Penerapan Model PBL Menggunakan Alat Peraga Sederhana Terhadap Hasil Belajar Murid. Jurnal curricula, 3(1).

[33] Sulistyowati, N., Widodo, A.T., \& Sumarni, W. (2012). Efektivitas Model Pembelajaran Guided Discovery Learning terhadap Kemampuan Pemecahan Masalah Kimia. Chemistry in Education, 2(1), 49-55.
[34] Sundayana R. (2016). Media dan alat peraga dalam pembelajaran matematika. Bandung: Alfabeta.

[35] Supriyanto, B. (2014). Penerapan Discovery Learning untuk Meningkatkan Hasil Belajar Murid Kelas IV B Mata Pelajaran MatematikaPokok Bahasan Keliling dan Luas Lingkaran di SDN Tanggul Wetan 02 Kecamatan Tanggul Kabupaten Jember. Jurnal Pancaran, 3(2),165-174.

[36] Wahjudi, E. (2015). Penerapan Discovery Learning dalam Pembelajaran IPASebagai Upaya untuk Meningkatkan Hasil Belajar Siswa Kelas IX-I di SMP Negeri 1 Kalianget.LENSA (Lentera Sains): Jurnal Pendidikan IPA, 5(1).

[37] Walker, R. J. et al. (2018). Comparing active learning techniques: The effect of clickers and discussion groups on student perceptions and performance. Australasian Journal of Educational Technology, 34(3), s. $\quad$ 74-87. doi:10.14742/ajet.3337.

[38] Wena, M. (2011). Strategi Pembelajaran Inovatif Kontemporer: Suatu Tinjauan Konseptual Operasional. Jakarta: Bumi Aksara.

[39] Widhiyantoro, T., Indrowati, M., \& Probosari, R. M. (2012). The Effectiveness of Gided Discovery Method Application Toward Creative Thinking Skill at The Tenth Grade Students of SMA N 1 Teras Boyolali in The Academic Year 2011/2012. Jurnal Pendidikan Biologi, $4(3), 89-99$.

[40] Widoyoko, E. P. (2009). Evaluasi Program Pembelajaran: Panduan Praktis bagi Pendidik dan Calon Pendidik. Yogyakarta: Pustaka Pelajar.

[41] Widyaningsih, S. W., Yusuf, I. (2015). Penerapan Quantum Learning Berbasis Alat Peraga Sederhana untuk Meningkatkan Hasil Belajar Peserta Didik. Jurnal Ilmiah, 10(3).

[42] Yamsari, Y. (2010). Pengembangan Media Pembelajaran Matematika Berbasis ICT yang Berkualitas. Seminar Nasional Pasca Sarjana X ITS. Institut Teknologi Sebelas Maret. 
Edumaspul: Jurnal Pendidikan, 3 (2), 2019 - 139 Delora Jantung Amelia \& Bahrul Ulumu

[43] Zuhdan, K. P. (2011). Pengembangan Perangkat Pembelajaran Sains Terpadu Untuk Meningkatkan Kognitif, Keterampilan Proses, Kreativitas serta Menerapkan Konsep Ilmiah Peserta Didik SMP. Tesis. Yogyakarta: Program Pascasarjana UNY.

\section{Profil Penulis:}

Penulis pertama yaitu Irmawati M, S.Pd merupakan mahasiswa pascasarjana magister pendidikan dasar di Universitas Muhammadiyah Makassar. Penulis lahir di Solie, 16 Januari 1994. Pendidikan sarjana S1 ditempuh di Universitas Muhammadiyah Makassar jurusan Pendidikan Guru Sekolah Dasar (PGSD).
Penulis kedua yaitu Dr. Rukli, M.Pd., M.Cs merupakan dosen di pascasarjana Universitas Muhammadiyah Makassar. Pendidikan penulis adalah doktor dibidang matematika.

Penulis ketiga yaitu Dr. Baharullah M.Pd merupakan dosen di pascasarjana Universitas Muhammadiyah Makassar. Pendidikan penulis adalah doktor dibidang matematika. 